\title{
Review on the Compositional Variation of Eudialyte-Group Minerals in the Ilímaussaq Complex (South Greenland)
}

\author{
Michael A.W. Marks ${ }^{1, *}$, Hans G.M. Eggenkamp ${ }^{1}$ (D) Petya Atanasova ${ }^{1,2}$, Felicitas Mundel ${ }^{1}$, \\ Sascha Kümmel ${ }^{1}$, Matthias Hagen ${ }^{1}$, Thomas Wenzel ${ }^{1}$ and Gregor Markl ${ }^{1}$ \\ 1 Department of Geosciences, Eberhard-Karls-Universität Tübingen, 72076 Tübingen, Germany; \\ hans@eggenkamp.info (H.G.E.); p.atanasova@hzdr.de (P.A.); felicitas.mundel@gmail.com (F.M.); \\ s.kuemmel_geo@hotmail.com (S.K.); mf.hagen@web.de (M.H.); thomas.wenzel@uni-tuebingen.de (T.W.); \\ gregor.markl@uni-tuebingen.de (G.M.) \\ 2 Helmholtz-Zentrum Dresden-Rossendorf, Helmholtz Institute Freiberg for Resource Technology, \\ 09599 Freiberg, Saxony, Germany \\ * Correspondence: michael.marks@uni-tuebingen.de
}

Received: 13 October 2020; Accepted: 10 November 2020; Published: 13 November 2020

\begin{abstract}
We review the compositional variation of eudialyte-group minerals (EGM) from the Ilímaussaq complex in South Greenland. Investigated samples cover all major rock units and associated pegmatites and aplites. The whole data set ( $>3000$ analyses from $>250$ samples) exhibits variable XMn (0.1-0.5), REE (0.2-1.7 apfu), $\mathrm{Nb}(0.1-0.4)$, and $\mathrm{Cl}$ contents (0.4-1.6 apfu). Most EGM compositions are Na-rich (13-15 apfu), while deviations to Na-rich but also to Na-poor compositions occur because of a combination of primary features (peralkalinity, water activity) and secondary alteration. During magma evolution, REE contents in EGM cores generally increase and reach their highest contents in the most evolved rock units of the complex. This points to the moderate compatibility of REE in EGM and a bulk D (cEGM/cmelt) value of $<1$ during magma differentiation. Chlorine contents in EGM cores continuously decrease, and are lowest at the rims of individual crystals, suggesting a continuous decrease of $\mathrm{Cl}$ activity in the magmas by large-scale EGM and sodalite extraction during the orthomagmatic stage and water enrichment during the late-magmatic stage. The overall variations of XMn across stratigraphy are only minor and likely influenced by the co-crystallization of sodic pyroxene and amphibole (c.f. aegirine, arfvedsonite) and local phase proportions. Similarly, $\mathrm{Nb}$ and Ti contents are influenced by co-crystallizing aenigmatite, rinkite, and others. Their presence buffers $\mathrm{Ti}$ and $\mathrm{Nb}$ contents to rather constant and low values, while their absence may cause variable enrichment on a local scale. Very low Sr contents $(<0.1 \mathrm{apfu})$ in magmatic EGM from Ilímaussaq are related to the basaltic nature of the parental magmas of the complex, as large-scale plagioclase fractionation occurred prior to the formation of the Ilímaussaq magmas, effectively removing $\mathrm{Sr}$ from the system. This is in line with very strong negative Eu anomalies in EGM from Ilímaussaq. Consistently, Sr contents in EGM from alkaline complexes, for which foiditic parental magmas are assumed, are much higher and, in such cases, negative Eu anomalies are generally absent.
\end{abstract}

Keywords: Ilimaussaq; differentiation; eudialyte-group minerals; mineral chemistry

\section{Introduction}

Minerals of the eudialyte-group (EGM) are a complex group of mostly Na- and Ca-rich Zr-silicates with variable amounts of $\mathrm{K}, \mathrm{Sr}, \mathrm{Fe}, \mathrm{Mn} \mathrm{REE}, \mathrm{Y}, \mathrm{Nb}$, Ti, and other elements. Their International Mineral Association-approved general formula is $\mathrm{N}_{15-16} \mathrm{M}(1)_{6} \mathrm{M}(2)_{3} \mathrm{Z}_{3} \mathrm{M}(3) \mathrm{M}(4) \mathrm{Si}_{24} \mathrm{O}_{66-73}(\mathrm{OH})_{0-9} \mathrm{X}_{2}$. 
Members of the eudialyte-group are known from roughly 100 localities worldwide, defining so-called agpaitic rocks, as recently reviewed by [1]. They mostly occur in pegmatites or late-stage dyke rocks that crosscut otherwise miaskitic rocks (e.g., Magnet Cove, Kovdor, Dara-i-Pioz) or as interstitial phases dispersed in spatially restricted areas of otherwise miaskitic rocks (e.g., Tamazeght, Pilanesberg, Junguni). These occurrences show large differences in terms of areal extent and abundance of EGM-bearing dyke rocks. In some cases, they are documented only by a single dyke rock or by only tens of meters-sized areas (e.g., [2-4]). In these cases, EGM crystallized from evolved residual liquids derived from otherwise much larger magmatic systems. Less common are composite magmatic complexes with minor but significant agpaitic rock units (e.g., Pocos de Caldas, Mont Saint-Hilaire) and at only few localities do agpaitic rocks constitute the dominant rock units of composite magmatic complexes, where EGM are common rock-forming minerals in the magmatic units and in associated pegmatites and hydrothermal veins (e.g., Ilímaussaq, Khibina, and Lovozero).

The eudialyte group is structurally and compositionally diverse and currently comprises 25 IMA-approved end members, with more to be expected [5]. Several of these end members have only recently been described and are comparatively rare, typically occurring only in very rare pegmatites or late-stage veins. The compositional variation of EGM from localities where they are relatively abundant and represent important rock-forming minerals is less diverse, generally described as solid solutions between the end members eudialyte, manganoeudialyte, kentbrooksite, ferrokentbrooksite, zirsilite and few others $[4,6-8]$. Other rock-forming mafic minerals at such occurrences (e.g., clinopyroxene and amphibole) are often approaching endmember compositions and provide comparatively little information on the geochemical evolution path in such magmatic systems. Therefore, attempts have been made to link the compositional variability in magmatic EGM to magmatic and hydrothermal processes $[4,6,9,10]$.

The Ilímaussaq complex in south Greenland is one of the few key localities where EGM crystallization started during orthomagmatic stages and persisted throughout the differentiation history of the whole complex that largely evolved under closed system conditions [1]. It therefore offers the possibility to study compositional changes in EGM during the evolution of EGM-saturated liquids. Moreover, Ilímaussaq is the place where the group-defining end member eudialyte was first discovered [11] and where taseqite, a Sr-rich end member was defined [12].

Here we review an extensive data set (>3000 analyses) of EGM from the Ilímaussaq complex comprising previously published and new electron microprobe data from all major rock units. The largest part of the data set represents electron microprobe data from various laboratories using different analytical protocols, while systematic trace element data are comparatively rare $[6,13]$. We discuss variations that occur within and between grains of single samples and compare them to intrusion-wide variations. We then use these data to identify compositional parameters and link them to magmatic and hydrothermal processes. Finally, a comparison is made to EGM compositions from several other key localities and we show that the general EGM chemistry at a given locality can be used to characterize the nature of parental magma and fluid sources, depending on the relative timing of EGM formation (early magmatic, late magmatic, hydrothermal).

\section{Geology of the Ilímaussaq Complex}

Extensive reports on the geology and mineralogy of the Ilímaussaq complex are available [13-15] that are reviewed in [16-18]. Briefly, the complex consists of three major rock series: (1) metaluminous augite syenite, (2) peralkaline granite and quartz syenite and (3) different varieties of mostly peralkaline and EGM-bearing nepheline syenites (Figure 1 left). We focus here on the general characteristics of the major EGM-bearing rock units, which dominate the complex. This agpaitic suite comprises three major rock series that are divided here in a floor section, a roof section and an intermediate section for convenience (Figure 1 right). Most rocks that form these three sections are mineralogically similar, consisting of variable proportions of felsic minerals (alkali feldspar, nepheline and sodalite), mafic phases (sodic pyroxene, Na-amphibole, aenigmatite and EGM) and various accessories. They are, 
however, distinguished based on their general texture, grain size, grain size distribution as well as fabric, as detailed below. Each of these three sections resembles continuously exposed rock series of several hundreds of meters thickness that allow to relate the various rocks types to each other. The detailed genetic relationships between these three sections have been intensively discussed [9,10,19-22].

\subsection{Floor Section}

This section represents the lowermost exposed rocks of the complex and provides continuous outcrop over a thickness of about $300 \mathrm{~m}$ (Figure 2A). Rhythmically layered and coarse-grained rocks (lower layered kakortokites; LLK) are dominant but grade upwards into similar rocks in which rhythmic layering is less well developed (slightly layered kakortokites; SLK). Formation models for this layered sequence range from closed-system formation by crystal settling and mat formation $[9,21,23]$ to open-system models invoking multiple replenishment events and mostly in-situ growth of crystals [22].

Discordant to the layering developed in the LLK, a heterogeneous rock unit that is up to several tens of meters thick is locally exposed. The rocks of this unit have been originally termed "slumped kakortokites" [24], but recently, this unit has been interpreted to represent hybrid rocks that formed from independent magma bodies that interacted with the then partly consolidated LLK crystal mush during emplacement $[25,26]$.

A marginal pegmatite zone occurs mostly along the contact between the LLK and the surrounding EGM-free syenites (so-called augite syenites). This unit consists of an irregular network of pegmatite bands and patches set in a matrix of equigranular medium- to coarse-grained rocks that largely resemble rocks of the LLK ([17]; Figure 2B). The thickness of this unit varies from about $100 \mathrm{~m}$ in the lowermost to about $25 \mathrm{~m}$ thickness in the uppermost levels.

Further, aplitic rocks occur within the floor sequence at different stratigraphic levels as irregularly formed and up to several meter large bodies of heterogeneous but rather leucocratic rocks (Figure 2C). They largely consist of albite, nepheline, sodalite, analcite and eudialyte and contain variable amounts of aegirine, arfvedsonite and other accessory minerals. These leucocratic bodies are irregularly shaped and may represent residual liquids that segregated and were mobilized due to compaction of the host layered kakortokite sequence (LLK + SLK). 

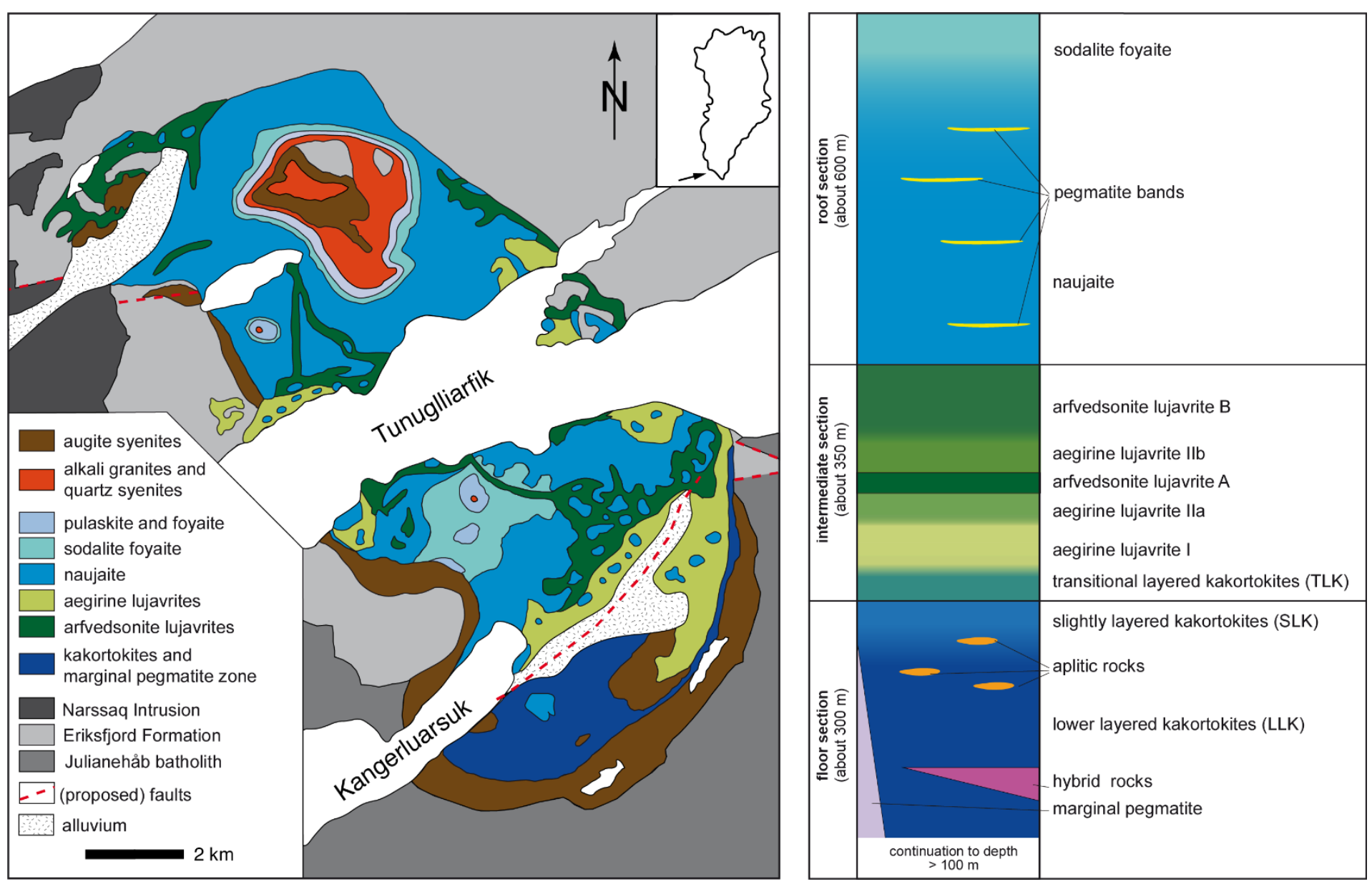

Figure 1. Schematic map from the Ilímaussaq Complex (left) and division of the agpaitic rocks (right) into three sections. 

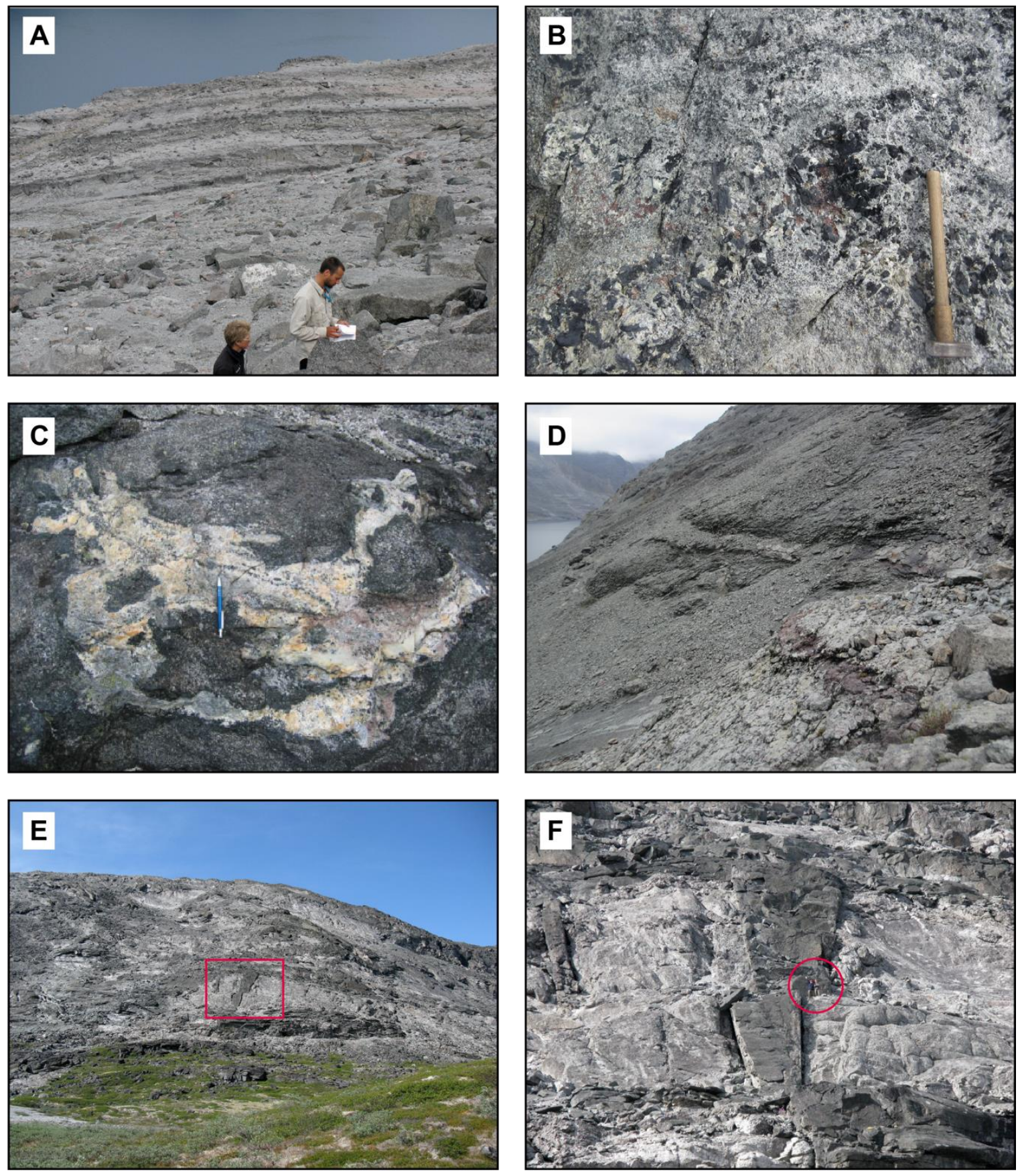

Figure 2. Field aspects of various rocks from the Ilímaussaq Complex, South Greenland. (A): Rhythmically layered rocks of the floor section (lower layered kakortokites, LLK). (B): The marginal pegmatite zone consisting of an irregular network of pegmatite bands and patches set in a matrix of equigranular medium- to coarse-grained rocks that largely resemble rocks of the LLK. (C): Leucocratic aplite exposed as an irregularly formed and up to several meters large body within the LLK. (D): Subhorizontal pegmatite band (about $30 \mathrm{~cm}$ thickness) within the rocks of the floor section (naujaites). (E) Dark rocks of the intermediate section (lujavrites) intruding paler roof zone rocks (naujaites). (F) A magnification of the red box in Figure 2E, with people (round circle) in the center for scale.

\subsection{Roof Section}

This sequence represents the uppermost agpaitic rocks of the complex comprising mainly sodalite foyaites and naujaites. It is exposed over 500-600 m thickness and represents the volumetrically 
dominant unit of the complex (Figure 1). The rocks are generally coarse-grained and are interpreted to have formed by downward solidification, either representing flotation cumulates conjugate to the floor cumulates or representing a magma batch independent of the kakortokites (see details in [18]). The sequence displays macro-layering that is defined by subhorizontal several dm-thick pegmatite bands; some of them can be traced in the field over appreciable distances (Figure 2D). No contact between the floor section and the roof section is exposed. However, meter-scale autoliths of roof section rocks entrained in a specific LLK horizon suggest that at least parts of the roof section were already solidified during layering formation in the floor section (see below).

\subsection{Intermediate Section}

This section largely consists of medium- to fine-grained, mostly melanocratic and porphyritic rocks that often show magmatic fabrics and are named lujavrites. Based on the modal abundance of clinopyroxene (aegirine) and amphibole (arfvedsonite), green varieties are distinguished from black ones and several rare and locally restricted varieties have been described as well $[10,15,27-31]$. The lujavrites intrude rocks of the roof section as sub-horizontal (Figure 2E) sheets in places further propagating sub-vertically (Figure $2 \mathrm{~F}$ ), while direct field relations between lujavrites and rocks of the floor section are not exposed. Based on their mineralogy and geochemistry, however, they represent the most evolved units of the complex [32].

The largest and most coherent occurrence of the lujavrites is in the southeastern part of the complex, continuously exposed over a thickness of about $350 \mathrm{~m}$ (Figure 1). Structural data imply that this sequence represents a sill-like structure with a steep feeder zone that flattens out over short distances [10]. The steeper part of this sequence is dominated by aegirine lujavrite, grading upwards into arfvedsonite lujavrite, and intersected by further sub-horizontal sheets of arfvedsonite lujavrite. Thus, the lujavrite sequence developed through differentiation from a single magma batch, occassionally interrupted by melt replenishment or magma/crystal mush redistributions [10,21].

The lowest part of the sequence comprises strongly layered rocks (classically called transitional layered kakortokites; TLK), rather similar to the LLK. Classically, the TLK sequence was assigned to the structurally highest level of the kakortokites, but the field relations to the LLK are obscured by alluvial deposits. We assign these rocks to the lowermost exposed intermediate section, as these continuously develop into the overlying lujavrites (see details in $[10,18,20]$ ).

\section{Textural Appearance of EGM}

In floor section rocks, EGM is a euhedral cumulus phase (Figure 3A). The euhedral cores are occasionally overgrown by compositionally distinct rims that fill interstitial spaces and represent intercumulus EGM formation in the solidifying crystal mush (Figure 3B). Some of the hybrid rocks and aplitic rocks contain additional poikilitic EGM that is rich in albite inclusions (Figure $3 \mathrm{C}$ ) and is occasionally overgrowing euhedral nepheline (Figure 3D). In samples from the intermediate section, EGM is an early magmatic phase with variable zoning features (Figure 3E) and often occurs as phenocrysts (Figure 3F).

In contrast, most samples from the roof cumulates contain interstitial EGM, alkali feldspar, nepheline, arfvedsonite, aegirine and euhedral sodalite (Figure 3G). In samples from interlayered pegmatite beds, EGM may be euhedral, though.

Thus, the magmas from which the floor and intermediate sections formed, reached EGM saturation during early magmatic stages and EGM continuously crystallized until the late magmatic stages and during pegmatite formation. Accepting that euhedral sodalite in the roof cumulates crystallized very early and floated upwards, EGM in these rocks crystallized from the interstitial melt surrounding this sodalite mush. During pegmatite formation in these rocks, EGM is a cumulus phase. 

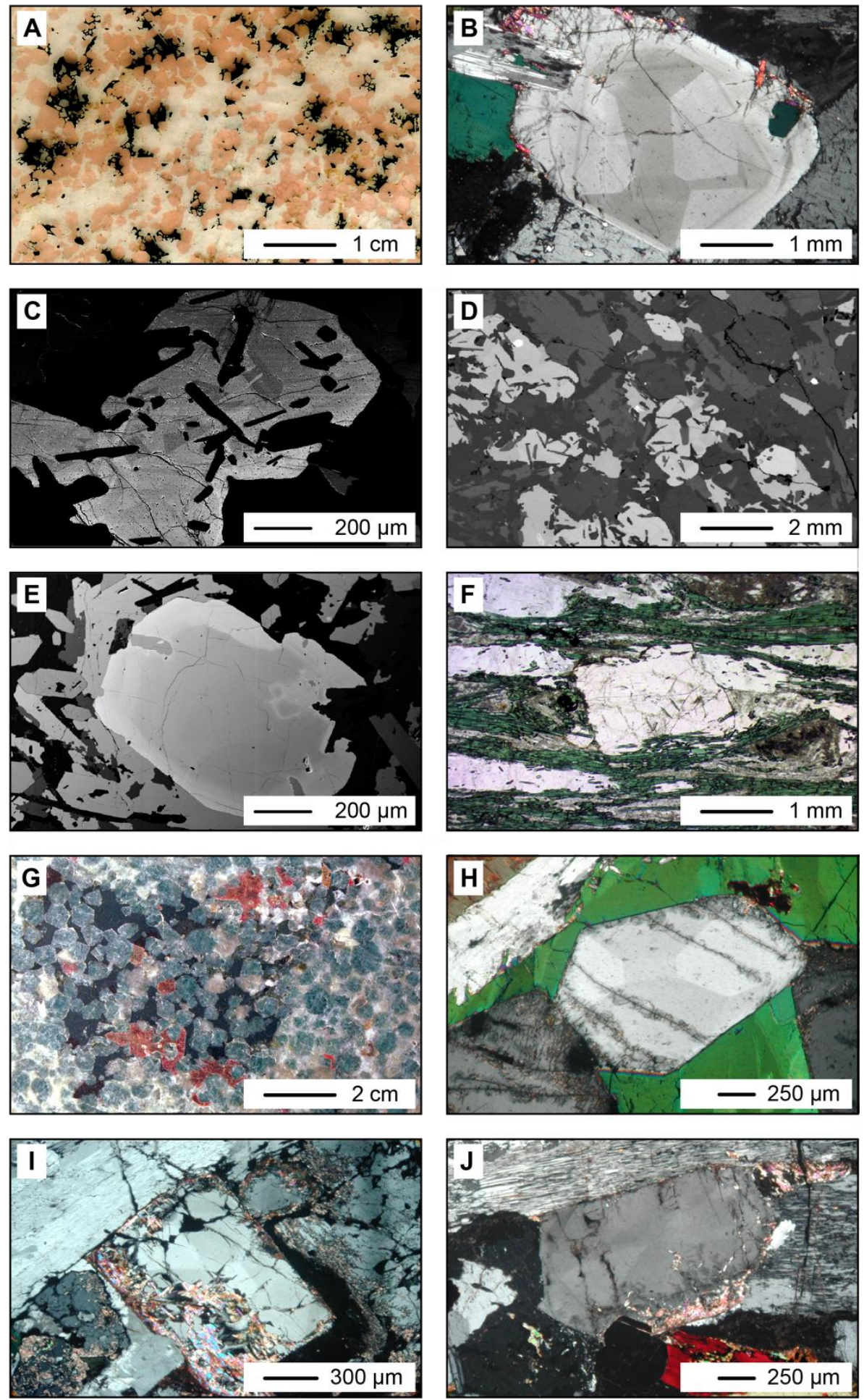

Figure 3. Textural appearance of eudialyte-group minerals (EGM) from various rocks of the Ilímaussaq complex, South Greenland. (A): Mostly euhedral to subhedral cumulus EGM in a floor cumulate. (B): Euhedral EGM core that shows oscillatory and sector zonation, showing overgrowth rim of inter cumulus EGM. (C,D): Poikilitic EGM from hybrid rocks with inclusions of albite and partly overgrowing nepheline. (E): Zoned EGM in an arfvedsonite lujavrite from the intermediate section. (F): Phenocryst of EGM in an aegirine lujavrite from the intermediate section. (G): Interstitial EGM (reddish), arfvedsonite (black) and alkali feldspar/ nepheline (white) and euhedral sodalite (bluish-green= in a roof cumulate rock. (H): Cracks in a sector zoned EGM from a floor cumulate rock. (I): Alteration assemblages forming along cracks and rims of otherwise fresh EGM. (J): Cracks with distinct EGM composition that are partly filled with secondary assemblages and invade otherwise fresh EGM. 
Compositional zoning of EGM is variable: In rocks of the floor series, EGM grains frequently show combinations of (1) sector zonation and (2) oscillatory growth zonation to variable extents, in cases combined with (3) compositionally distinct rims around parts or the entire euhedral core of the crystals. In roof series rocks and samples from the intermediate section, sector zonation features in EGM are less common, but do occur to variable extent.

1. Sector zonation is of primary high-temperature magmatic origin and reflects preferential incorporation of certain elements in different growth directions (e.g., $[9,21])$.

2. The significance of oscillatory growth zonation in eudialyte was never discussed and interpreted in detail. In general, however, hypotheses to explain such features range from representing (a) multiple magma recharge events to (b) differences in the velocity of crystal growth rates relative to diffusional transport in the surrounding liquid (e.g., [33]).

3. Subhedral and interstitial rims around mostly euhedral EGM cores have been interpreted as representing intercumulus growth in crystal mushes during compaction and aging [21]. Most interestingly, these rims may show a stronger or weaker brightness in BSE images (back-scattered electrons) compared to the cores (discussed below).

In most rock types, thin cracks through EGM crystals exist, along which EGM are still stable but compositionally distinct based on BSE imaging (Figure $3 \mathrm{H}$ ). Such textures represent post-magmatic fluid interaction. As is commonly observed, eudialyte may be altered and transformed to mineralogically diverse secondary assemblages, as previously discussed in detail (Figure 3I; [34]). The distinct EGM compositions along cracks (Figure 3J) may therefore represent the initial stages of such transformations.

\section{The Data Set}

Large data sets that document the compositional variation of EGM from Ilímaussaq have been presented by several authors [9,10,20-22,35], all focusing on rocks that constitute the floor and intermediate sections. We added data for EGM from roof section rocks and from previously unpublished MSc theses [26,36,37]. Now, this unique data set consists of more than 3000 modern EGM analyses from all three rock sections (Supplementary Table S1). All data are based on electron probe micro analyses (EPMA) using wavelength-dispersive spectrometers (WDS) and derive from four different labs (Tübingen and Freiberg, Germany; Oslo, Norway; St. Andrews, UK). The analytical protocols applied similar conditions $(10-25 \mu \mathrm{m}$ beam diameter to avoid Na migration and minimize beam damage effects [38], 15-20 kV acceleration voltage, 15-20 nA beam current), counting times and well-established reference materials, in some cases applying peak overlap corrections (Nd-Zr, Ti-Hf; e.g., $[9,38])$. We detected no significant or systematic differences between the data from various labs and therefore treat the data set in the following as a whole. Note that F was not analysed because of different interferences that cause high detection limits at about 0.1 to $0.15 \%$. However, F may be a significant component in EGM and bulk data for EGM from Ilímaussaq based on combustion ion chromatography indicate F contents up to $4000 \mu \mathrm{g} / \mathrm{g}$ [39].

All formulae were calculated based on $(\mathrm{Si}+\mathrm{Zr}+\mathrm{Ti}+\mathrm{Nb}+\mathrm{Hf}+\mathrm{Al})=29$ apfu and because of the structural complexity of EGM, cation assignment to specific structural sites is not always straightforward $[6,21,40,41]$. Detailed crystallographic investigations and additional analytical methods would be necessary to calculate specific end member compositions for each analysis. Therefore, we present the data as total apfu (atoms per formula unit).

The whole data set (electronic supplement) is illustrated as triplets of charts (Figures 4 and 5), according to the relative stratigraphic position of the analyses in each of the three rock sections described above. Based on the available data, magmatic EGM from Ilímaussaq are generally Na-rich (mostly 13-15 apfu), very Sr-poor (below $0.1 \mathrm{apfu})$, with variable XMn (0.1-0.5), REE (0.2-1.7 apfu), and $\mathrm{Cl}$ contents (0.4-1.6 apfu) and contain relatively low amounts of $\mathrm{Nb}$ (mostly $0.1-0.4)$. Thus, much of the overall compositional variation of magmatic EGM in Ilímaussaq can be described as solid solutions between the major end members eudialyte, manganoeudialyte and kentbrooksite, although the latter 
has been defined as a F endmember (see discussion in [41]). In some cases, Na-rich end members (e.g., raslakite) as well as Na-poor end members (e.g., aqualite) are of certain importance (see Table 1 for end member formulae).

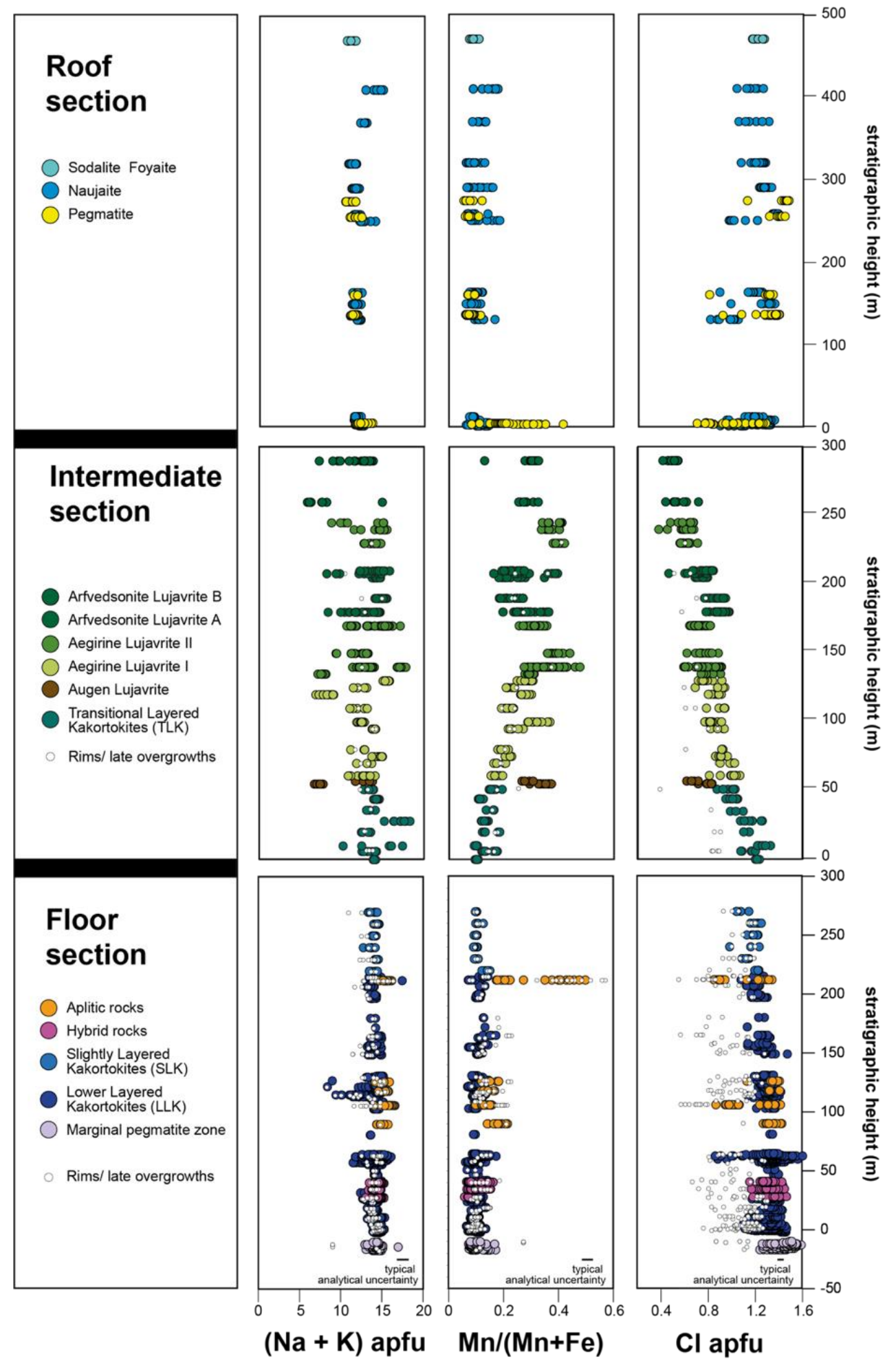

Figure 4. Compositional variation of eudialyte-group minerals (EGM) across the three major stratigraphic sections of the Ilímaussaq Complex, south Greenland expressed as $(\mathrm{Na}+\mathrm{K})$ apfu, $\mathrm{Mn}(\mathrm{Mn}+\mathrm{Fe})$ and $\mathrm{Cl}$ apfu. 


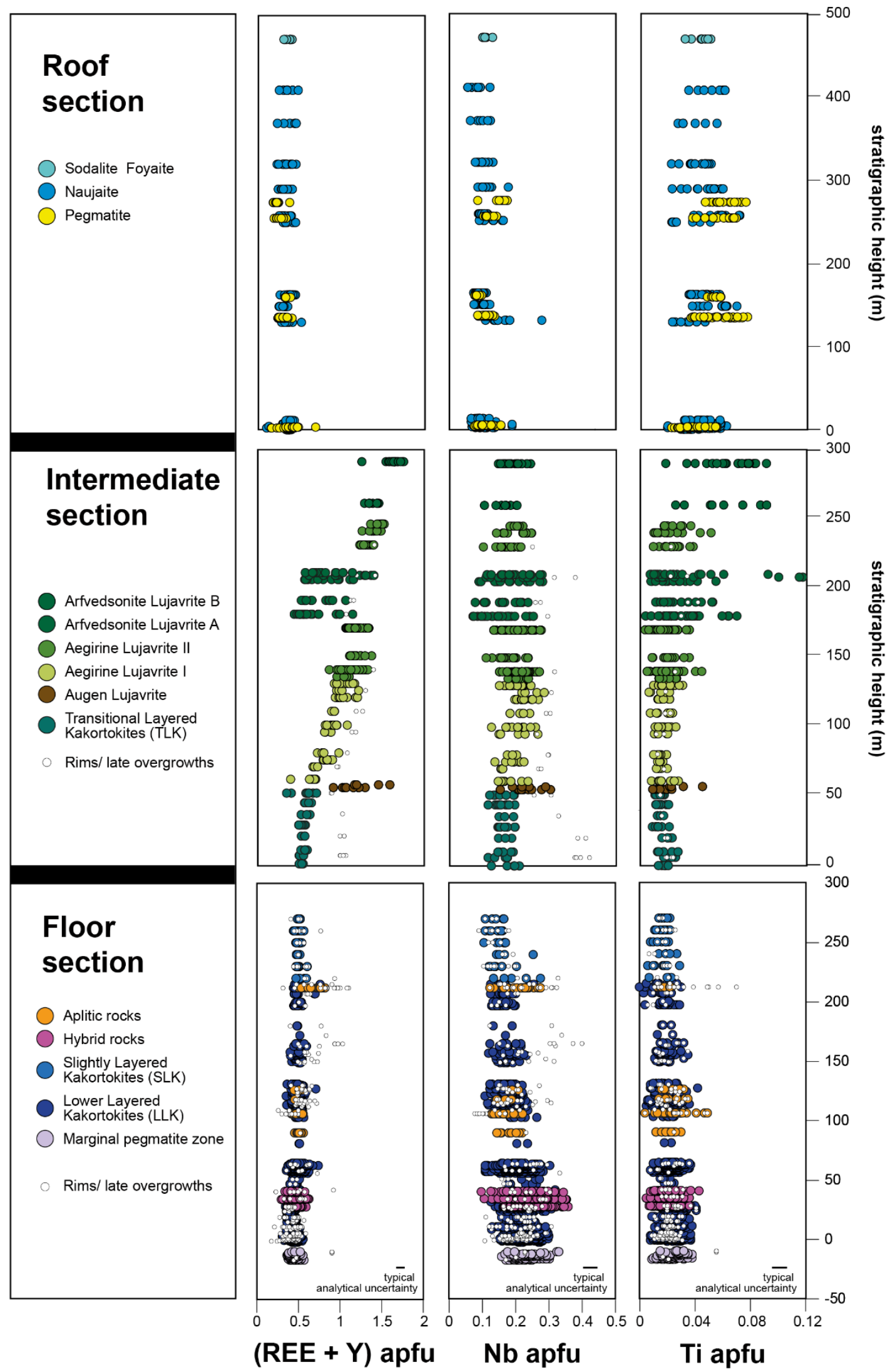

Figure 5. Compositional variation of eudialyte-group minerals (EGM) across the three major stratigraphic sections of the Ilímaussaq Complex, south Greenland expressed as (REE + Y) apfu, $\mathrm{Nb}$ apfu and Ti apfu. 
Table 1. Formulae for end members of the eudialyte-group mentioned in the text.

\begin{tabular}{|c|c|}
\hline End Member & Formula \\
\hline Eudialyte & $\mathrm{Na}_{15} \mathrm{Ca}_{6} \mathrm{Fe}_{3} \mathrm{Zr}_{3} \mathrm{Si}\left(\mathrm{Si}_{25} \mathrm{O}_{73}\right)\left(\mathrm{O}, \mathrm{OH}, \mathrm{H}_{2} \mathrm{O}\right)_{3}(\mathrm{Cl}, \mathrm{OH})_{2}$ \\
\hline Manganoeudialyte & $\mathrm{Na}_{14} \mathrm{Ca}_{6} \mathrm{Mn}_{3} \mathrm{Zr}_{3}\left[\mathrm{Si}_{26} \mathrm{O}_{72}(\mathrm{OH})_{2}\right]\left(\mathrm{H}_{2} \mathrm{O}, \mathrm{Cl}, \mathrm{O}, \mathrm{OH}\right)_{6}$ \\
\hline Kentbrooksite & $(\mathrm{Na}, \mathrm{REE})_{15}(\mathrm{Ca}, \mathrm{REE})_{6} \mathrm{Mn}_{3} \mathrm{Zr}_{3} \mathrm{Nb}\left(\mathrm{Si}_{25} \mathrm{O}_{73}\right)\left(\mathrm{O}, \mathrm{OH}, \mathrm{H}_{2} \mathrm{O}\right)_{3}(\mathrm{~F}, \mathrm{Cl})$ \\
\hline Raslakite & $\mathrm{Na}_{15} \mathrm{Ca}_{3} \mathrm{Fe}_{3}(\mathrm{Na}, \mathrm{Zr})_{3} \mathrm{Zr}_{3}(\mathrm{Si}, \mathrm{Nb}) \mathrm{Si}_{25} \mathrm{O}_{73}\left(\mathrm{OH}, \mathrm{H}_{2} \mathrm{O}\right)_{3}(\mathrm{Cl}, \mathrm{OH})$ \\
\hline Aqualite & $\left(\mathrm{H}_{3} \mathrm{O}\right)_{8}(\mathrm{Na}, \mathrm{K}, \mathrm{Sr})_{5} \mathrm{Ca}_{6} \mathrm{Zr}_{3} \mathrm{Si}_{26} \mathrm{O}_{66}(\mathrm{OH})_{9} \mathrm{Cl}$ \\
\hline Zirsilite & $(\mathrm{Na}, \square)_{12}(\mathrm{Ce}, \mathrm{Na})_{3} \mathrm{Ca}_{6} \mathrm{Mn}_{3} \mathrm{Zr}_{3} \mathrm{NbSi}_{25} \mathrm{O}_{73}(\mathrm{OH})_{3}\left(\mathrm{CO}_{3}\right) \cdot \mathrm{H}_{2} \mathrm{O}$ \\
\hline Oneillite & $\mathrm{Na}_{15} \mathrm{Ca}_{3} \mathrm{Mn}_{3} \mathrm{Fe}_{3} \mathrm{Zr}_{3} \mathrm{Nb}\left(\mathrm{Si}_{25} \mathrm{O}_{73}\right)\left(\mathrm{O}, \mathrm{OH}, \mathrm{H}_{2} \mathrm{O}\right)_{3}(\mathrm{OH}, \mathrm{Cl})_{2}$ \\
\hline Taseqite & $\mathrm{Na}_{12} \mathrm{Sr}_{3} \mathrm{Ca}_{6} \mathrm{Fe}_{3} \mathrm{Zr}_{3} \mathrm{NbSi}_{25} \mathrm{O}_{73}\left(\mathrm{O}, \mathrm{OH}, \mathrm{H}_{2} \mathrm{O}\right)_{3} \mathrm{Cl}_{2}$ \\
\hline
\end{tabular}

Importantly, considerable variation of $\mathrm{XMn}, \mathrm{REE}, \mathrm{Nb}$ and $\mathrm{Cl}$ is related to sector-zonation of single grains (e.g., $[9,21])$ and such within-grain variations may cover the overall compositional variation within samples. Oscillatory zonation features are, however, difficult to quantify because the individual oscillations are generally thinner than the beam size required for EPMA analyses (20-25 $\mu \mathrm{m})$.

\section{Discussion}

In the following, we will discuss several key compositional parameters and comment on their potential implications on a local and on the intrusion scale, as well as on their significance for tracking magma chamber processes, evaluating hydrothermal overprint, and constraining the nature of the parental magma from which EGM eventually crystallized.

\subsection{Reasons for the Compositional Variation of EGM in the Ilimaussaq Rocks}

\subsubsection{Na-K-Ca Systematics}

Structurally, $(\mathrm{Na}+\mathrm{K})$ and $\mathrm{Ca}$ are assigned to three different crystallographic sites: Normally, $(\mathrm{Na}+\mathrm{K})$ occupy the $\mathrm{N}$-site only, but are assigned to the $\mathrm{M}(2)$ site as well in very Na-rich end members (e.g., raslakite, oneillite) and parts of $(\mathrm{Na}+\mathrm{K})$ may be replaced by $\mathrm{Sr}, \mathrm{REE}, \mathrm{H}_{3} \mathrm{O}+$, and vacancies. Calcium is assigned to the $\mathrm{M}(1)$-site and rarely to the $\mathrm{N}$-site as well (e.g., in zirsilite) and is mainly exchanged by REE $+\mathrm{Y}$, although it might be replaced by $\mathrm{Fe}$ and $\mathrm{Mn}$ in Ca-poor end members (e.g., raslakite, oneillite) as well. Thus, for structural reasons, $\mathrm{Ca} /(\mathrm{Na}+\mathrm{K})$ ratios and Ca contents in EGM are not useful to track magma evolution, which is in contrast to other minerals, such as for example amphibole (e.g., [20]). Therefore, we focus on $\mathrm{Na}$ and $\mathrm{K}$ contents in the following.

Although being variable in detail, a large part of the data indicates high $(\mathrm{Na}+\mathrm{K})$ contents $>13$ apfu and reach the ideal value of 15 apfu $(\mathrm{Na}+\mathrm{K})$ for eudialyte sensu stricto (Figure 4). Overall, no systematic stratigraphic changes within the three sections are obvious. Some of the evolved rocks of the intermediate section contain exceptionally Na-rich EGM with up to about 18 apfu $(\mathrm{Na}+\mathrm{K})$. Such Na-rich compositions have been interpreted to result from extremely high peralkalinity during their crystallization [20]. Likewise, Na-poor compositions are frequently found in most rock types, in many cases representing rims of EGM crystals or analyses that are spatially associated with cracks. Such compositions have been discussed in the context of Na-loss because of the initial stages of eudialyte alteration (e.g., [20,42]) and are especially abundant in rocks of the intermediate section, which tend to show relatively strong hydrothermal overprint (e.g., [10]). However, three samples from the intermediate section contain several mm large EGM phenocrysts that are Na-poor (6-9 apfu $\mathrm{Na}+\mathrm{K}$ ) but lack any obvious alteration features. These compositions have been interpreted to represent a high aqualite component that directly crystallized from water-rich melts but is not related to hydrothermal alteration [20]. These analyses are also rather K-rich (up to $0.8 \mathrm{apfu}$ ), while in all other rocks, K contents are rather low (0.1-0.4 apfu), with only minor changes across the stratigraphy and rim analyses having the tendency to be relatively $\mathrm{K}$ rich compared to core analyses.

In all, $(\mathrm{Na}+\mathrm{K})$ contents in magmatic EGM from Ilímaussaq are generally high, while $\mathrm{K}$ is generally low. Deviations to Na-rich, but also to Na-poor and K-rich compositions do occur because of 
a combination of primary features (peralkalinity, water activity) and secondary alteration. The relative importance of these processes are locally variable, and the effects on EGM compositions are partly very similar, making it difficult to interpret $\mathrm{Na}, \mathrm{K}$ and $(\mathrm{Na}+\mathrm{K})$ contents of $\mathrm{EGM}$ in terms of magma evolution at an intrusion scale.

\subsubsection{Fe and Mn Contents}

The variation of Fe and Mn contents in EGM is expressed as XMn (Mn/Mn $\left.+\mathrm{Fe}_{\text {tot }}\right)$, assuming all Fe as ferrous, although previous studies showed that the $\mathrm{Fe}^{3+} / \mathrm{Fe}^{2+}$ of natural EGM may be influenced by post-crystallization hydration (e.g., [35,43]). Cores of EGM from the floor section show only minor variation in XMn (mostly 0.07-0.15), with slightly higher mean XMn values in the upper part of the sequence and the highest XMn values (up to about 0.55) in aplitic rocks. Similarly, interstitial EGM from the roof section is Mn-poor (XMn of around 0.1), with higher values (up to about 0.5) restricted to pegmatitic rocks (Figure 4). In the intermediate section, XMn in the lowermost rocks is approximately 0.1 and evolves upwards to 0.3-0.4 with significant scatter though, especially in the upper part of the section (Figure 4).

Limited experimental data under reduced conditions applicable to the Ilímaussaq system [44] suggest that the XMn in EGM reflects the XMn in the melt from which it crystallized. Thus, the relatively high XMn in some of the pegmatitic and aplitic rocks imply that magma differentiation causes relative enrichment of Mn over Fe (increasing XMn) in EGM. Consequently, EGM from the roof and the floor section crystallized from magmas of very similar composition (in terms of XMn) and show only minor effects of fractional crystallization on the intrusion scale. Note that local variations in XMn values have been variably discussed in $[9,21]$. In contrast, EGM from the intermediate section generally evolve upwards the sequence to comparatively high XMn values (up to about 0.4) and are more variable, suggesting more pronounced effects of fractional crystallization, combined with magmatic replenishment or dynamic redistribution of melts or crystal mushes within the Ilímaussaq magma chamber [10,21]. We suggest that the relatively small effects of fractional crystallization in the floor sequence compared to the intermediate sequence relate to their different evolutionary stages, with the floor series rocks representing lower and the intermediate series rocks higher solidification fractions of a common magma reservoir. Importantly, however, most Ilímaussaq rocks contain major amounts of sodic pyroxene (mostly aegirine) and amphibole (mostly katophorite-arfvedsonitess) containing similar amounts of Mn (up to about 2.5. wt.\%) but much more Fe (about 10-30 wt.\% FeO; $[9,10,18,20]$ ). Thus, EGM composition (in terms of XMn) is at least partly influenced by the co-crystallization of sodic pyroxene and amphibole and depending on transient phases proportions crystallizing, EGM may simply monitor the evolution of the magma or it can effectively extract enough Fe and Mn and drives changes of XMn in the magma (e.g., [10]).

\subsubsection{Contents of REE, $\mathrm{Nb}$ and $\mathrm{Ti}$}

Titanium contents in EGM are generally low (mostly <0.05 apfu), except for rocks of the upper part of the intermediate section, where Ti contents show pronounced scatter within samples and reach up to 0.12 apfu Ti (Figure 5). Niobium contents in EGM cores from the floor section decrease slightly upwards the sequence from about $0.2-0.3 \mathrm{apfu}$ to about $0.1-0.2 \mathrm{apfu}$. Interstitial EGM from the roof section have similar $\mathrm{Nb}$ contents $(0.1-0.3 \mathrm{apfu})$ with no obvious trend across the sequence. In EGM cores from the intermediate section $\mathrm{Nb}$ contents show no continuous trend, as in parts of the sequences $\mathrm{Nb}$ contents are stable and in other parts they increase upwards the sequence (Figure 5). The $($ REE $+Y)$ contents in EGM cores from the floor section (0.35-0.6 apfu) show a very subtle upwards increase (Figure 5). This increase is strongly enhanced upwards the intermediate section, where EGM cores reach up to $1.7 \mathrm{apfu}(\mathrm{REE}+\mathrm{Y})$, interrupted by an obvious "reset" in one of the lujavrite units, though (Figure 5). This suggests enrichment of $(\mathrm{REE}+\mathrm{Y})$ during differentiation, in line with relatively high REE + Y contents in some of the aplitic rocks and in some of the late-stage EGM rims (see details 
below). Interstitial EGM from the roof section contains about $0.25-0.45$ apfu with no obvious trend across the stratigraphy.

While experimentally determined EGM-melt partitioning data are not available, estimates based on titanite-eudialyte partitioning [45] suggest that REE are only slightly compatible (if at all) with the EGM structure. This is in line with the minor increase of REE + Y in EGM cores across the floor sequence and pronounced enrichment across the more evolved intermediate section. By comparison, $\mathrm{Nb}$ contents across the floor section actually decrease, while they are more or less stable across the intermediate section. These two contrasting features are very difficult to reconcile with either higher or lower compatibility of $\mathrm{Nb}$ in EGM compared to REE + Y alone. [21] explored the possibility for a coupled substitution mechanism in solid solution between eudialyte sensu stricto and kentbrooksite, as the latter is less centrosymmetric and $\mathrm{Nb}$ would be incorporated more easily. This would cause an increase of $\mathrm{Nb}$ partitioning coefficients in EGM during progressive enrichment of REE and Mn in EGM upwards the intermediate section, causing enrichment of $\mathrm{Nb}$ in EGM even though $\mathrm{Nb}$ is depleted in the coexisting melt. This is however, not the case (Figure 5).

Importantly, compositionally distinct EGM rims that are either relatively $\mathrm{Nb}-\mathrm{REE}+\mathrm{Y}$-rich or $\mathrm{Nb}-\mathrm{REE}+\mathrm{Y}$-poor have been documented $[9,21]$ and explained by co-crystallizing phases, such as rinkite, during the intercumulus stage Their presence would cause depletion of $\mathrm{Nb}$ and REE $+\mathrm{Y}$ in the intercumulus melt, causing Nb-REE + Y-poor EGM rims, while their absence would have the opposite effect (see details in [21]). However, because rinkite is Ti-rich, such effects would probably influence Ti contents in these overgrowth rims as well, which is, however, not obvious (Figure 5). This might be explained by the very low Ti contents and the associated high analytical uncertainty. Alternatively, the additional influence of aenigmatite might be considered, which is abundant in rocks of the floor and roof series but very rare in rocks of the intermediate section, especially in the upper parts of the intermediate section, where Ti contents in EGM increase again (Figure 5). It is important to note here, that the slightly different behaviour of relatively minor $\mathrm{Ti}, \mathrm{Nb}$, and $\mathrm{REE}+\mathrm{Y}$ contents in EGM cores from the floor and intermediate sections suggests that their incorporation into EGM depends on additional factors than melt composition and differences in partitioning coefficients/incorporation mechanisms, such as, e.g., the nature of co-crystallizing phases.

Co-crystallizing phases that incorporate $\mathrm{Ti}, \mathrm{Nb}$ and $\mathrm{REE}$ include aenigmatite and rinkite. Aenigmatite is Ti-rich (7-9 wt.\% TiO2; [46]) but contains only minor amounts of $\mathrm{Nb}$ and REE, while rinkite is very REE-rich (20 wt.\%) and contains both $\mathrm{Nb}$ and Ti at the wt.\% level [47]. Thus, in aenigmatite-bearing rocks, Ti contents in EGM may be buffered to relatively low contents, while in aenigmatite-free rocks, Ti contents may increase in EGM with ongoing differentiation, as is the case in the intermediate section. In turn, the absence of rinkite during magmatic stages allow for the enrichment of REE in EGM from rocks of the intermediate section. By analogy, $\mathrm{Nb}$ contents should increase as well, which is not the case. Although it is unclear, which processes in detail cause the slight differences in $\mathrm{Ti}, \mathrm{Nb}$ and $(\mathrm{REE}+\mathrm{Y}$ ) contents of EGM, it seems unlikely that $\mathrm{Nb}$ and Ti contents are directly related to their concentrations in the magma from which EGM crystallized.

\subsubsection{Chlorine Contents}

The slight gradual decrease in $\mathrm{Cl}$ contents upwards the roof section (from about 1.5 to $1.1 \mathrm{apfu}$ ) and more pronounced upwards the intermediate section (1.1 apfu to $0.5 \mathrm{apfu}$ ) and the tendency for relatively low $\mathrm{Cl}$ contents in interstitial EGM rims and EGM from aplites and pegmatites (Figure 4) suggest continuous removal of $\mathrm{Cl}$ from the system or depletion of $\mathrm{Cl}$ relative to water (increase of water activity) or a combination of both factors $[10,20,21]$. Note that interstitial EGM in the roof section contains generally around 1.1 apfu $\mathrm{Cl}$, with significant scatter between samples, but no obvious trend across the stratigraphy (Figure 4). As EGM in these rocks is interstitial, we suggest that their $\mathrm{Cl}$ contents do not reflect a single ortho magmatic stage but may be influenced by equilibration of local sub systems. 
Using a fractional crystallization model and experimental data [44], removal of EGM alone does not explain these observations, as this would result in a net increase of $\mathrm{Cl}$ in the residual melt at realistic modal EGM contents $(\leq 30 \%)$. Decreasing $\mathrm{Cl}$ contents in the magma are only achieved when additional sodalite is removed (Figure 6), as the latter is very Cl-rich (about $7 \mathrm{wt} . \% \mathrm{Cl}$ compared to $<2 \mathrm{wt} . \% \mathrm{Cl}$ in EGM). For example, to explain the $\mathrm{Cl}$ decrease in EGM with higher stratigraphic position in the lower sequence by about $20-30 \%$ (Figure 4 ), $>10 \%$ additional sodalite removal is necessary for $\mathrm{F}$ values $>0.5$ (Figure 6), which is more sodalite than actually present in the average floor series rocks. Even more so, strong $\mathrm{Cl}$ depletion upwards in the intermediate section (Figure 4), requires even larger amounts of sodalite removal (potentially combined with water enrichment and cooling). The roof series rocks are very sodalite-rich (typically $30-40 \mathrm{vol} . \%$ ) and as large autoliths of these rocks are accumulated at a certain LLK horizon, they must have been already solid, while LLK layering formation was still ongoing. Therefore, $\mathrm{Cl}$ extraction by sodalite removal was an important process before and (at least partly) during LLK formation. Hence, it is likely that sodalite-rich roof series rocks may have formed from the same parental magma as the floor series rocks. Still, whether the roof series and floor series rocks formed from a single parental magma or not remains an open question.

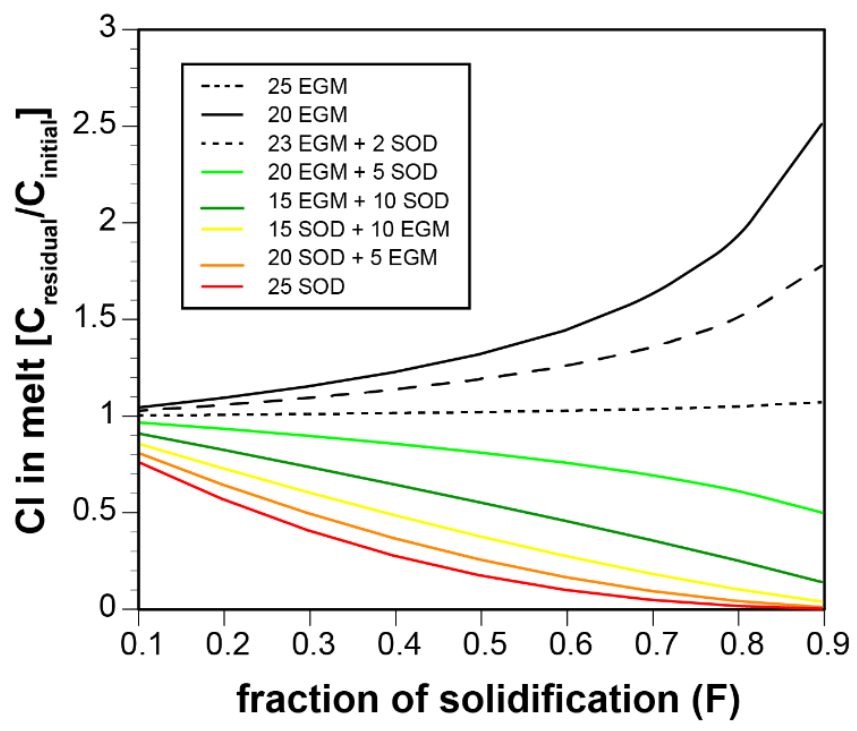

Figure 6. Fractional crystallisation model illustrating the effects of sodalite (SOD) and eudialyte-group mineral (EGM) removal on the $\mathrm{Cl}$ concentration in the residual magma (expressed as $\mathrm{C}_{\text {residual }} / \mathrm{C}_{\text {initial }}$ ) depending on the fraction of solidification $(\mathrm{F})$.

\subsection{Source Constraints}

Strontium contents in magmatic EGM from Ilímaussaq are invariably low (several hundreds of $\mu \mathrm{g} / \mathrm{g}$ ) and often below the detection limit of EPMA analyses. Most interestingly (and in apparent contradiction), Ilímaussaq is the type locality for the Sr-rich EGM endmember taseqite, described from small cavitites in a single hydrothermal albitite vein with Sr contents of around $14 \mathrm{wt} . \% \mathrm{SrO}$ [12]. Similar rather Sr-rich EGM compositions are known from other low-temperature EGM assemblages, for example from Sushina and Pilansberg [48,49]. Thus, very Sr-rich EGM seem to form under hydrothermal conditions and are therefore not necessarily related to the magmatic history of the complex, but strongly depend on the composition of the fluids from which such low-temperature assemblages crystallize. As such fluids may also be externally derived and have been shown to interacted with relatively Sr-bearing host rocks before (c.f. basalts; [50]), this could cause the low-temperature formation of Sr-rich EGM at Ilímaussaq.

Magmatic EGM with appreciable SrO are known from e.g., Khibina, Lovozero, Tamazeght, and Pocos de Caldas, in cases associated with other Sr-bearing phases, such as lamprophyllite or loparite $[4,8,35]$. Such magmatic Sr-rich assemblages may reflect the nature of their parental magma 
from which the evolved rocks formed. Magmatic EGM assemblages crystallize from magmas that derive from either basaltic or basanitic-foiditic parental melts [1,51]. Only in the first case, large amounts of plagioclase may fractionate, effectively removing $\mathrm{Sr}$ from the evolving magmas, because of the strong compatibility of Sr for plagioclase. In fact, Ilimaussaq is believed to reflect a key example for derivation from basaltic precursor magmas, in line with the very low Sr contents in magmatic EGM. Thus, the Sr content of magmatic EGM allows for distinguishing EGM-bearing rocks that evolved from basaltic or from basanitic to foiditic magmas, respectively.

Similarly, the shape of normalized REE patterns in EGM and the presence or absence of negative Eu anomalies, allows to distinguish foiditic-basanitic versus basaltic parental magmas, again because of the influence of plagioclase fractionation, which is significant in the case for basaltic precursor melts only. Foid minerals (nepheline, sodalite and melilite) are generally REE-poor and are not believed to cause such effects (e.g., [52,53]). Full primitive mantle-normalized REE patterns of EGM have been presented by $[20,21,35]$ and are characterized by an enrichment of LREE relative to HREE, which increases with total REE. All EGM have negative Eu anomalies $\left(\mathrm{Eu} / \mathrm{Eu}^{*}=0.2-0.4\right)$, with no systematic changes across the stratigraphy $\left(\mathrm{Eu}^{*}=\mathrm{EuN} \sqrt{/(\mathrm{SmN} * \mathrm{GdN})}\right)$. Across sequence (and within grains) $(\mathrm{La} / \mathrm{Yb}) \mathrm{N}$ increase slightly, driven by increasing $(\mathrm{Gd} / \mathrm{Lu}) \mathrm{N}$ but decreasing $(\mathrm{La} / \mathrm{Sm}) \mathrm{N}$, especially in rocks from the intermediate section.

\section{Conclusions}

Eudialyte-group minerals are potential monitors for a range of early magmatic, late magmatic, hydrothermal and alteration processes and may provide additional constraints on parental magma sources. A comprehensive electron microprobe data set on eudialyte-group minerals from the well-studied Ilímaussaq Complex (South Greenland) shows that the investigated compositional parameters $(\mathrm{Na}, \mathrm{Sr}, \mathrm{REE}, \mathrm{Nb}, \mathrm{Ti}, \mathrm{Cl}$ and $\mathrm{Mn} /(\mathrm{Mn}+\mathrm{Fe})$ ) are variably influenced by primary (magmatic) and secondary (hydrothermal) processes, and textural control of such data is essential for sound interpretations at the intrusion scale. The composition of eudialyte-group minerals is largely affected by co-crystallizing phases (e.g., sodalite, sodic pyroxene and amphibole, aenigmatite, and others), implying that eudialyte-group minerals monitor such changes rather than actively causing major changes in magma composition. The most reliable monitor in EGM for magma differentiation and replenishment seems to be the REE content, at least for the Ilímaussaq case.

Supplementary Materials: The following are available online at http://www.mdpi.com/2075-163X/10/11/1011/s1, Table S1: EGM data Ilímaussaq.

Author Contributions: Conceptualization, M.A.M. and G.M.; investigation, M.A.M., P.A., F.M., S.K., M.H., and T.W.; data curation, M.A.M., P.A., F.M., S.K., M.H., and T.W.; writing-original draft preparation, M.A.M.; writing-review and editing, M.A.M., H.G.E., P.A., F.M., S.K., M.H., T.W., and G.M.; funding acquisition, M.A.M. and G.M. All authors have read and agreed to the published version of the manuscript.

Funding: This research was funded by Deutsche Forschungsgemeinschaft (DFG), grant number MA2563/13 and by the European Union's (EU) Horizon 2020 research and innovation programma, grant agreement No 689909, HiTechAlkCarb.

Acknowledgments: We thank reviewers for their critical comments on an earlier version of the manuscript.

Conflicts of Interest: The authors declare no conflict of interest. The funders had no role in the design of the study; in the collection, analyses, or interpretation of data; in the writing of the manuscript, or in the decision to publish the results.

\section{References}

1. Marks, M.A.W.; Markl, G. A global review on agpaitic rocks. Earth Sc. Rev. 2017, 173, 229-258. [CrossRef]

2. Chukanov, N.V.; Moiseev, M.M.; Rastsvetaeva, R.K.; Rozenberg, K.A.; Zadov, A.E.; Pekov, I.V.; Korovushkin, V.V. Golyshevite $(\mathrm{Na}, \mathrm{Ca})_{10} \mathrm{Ca}_{9}\left(\mathrm{Fe}^{3+}, \mathrm{Fe}^{2+}\right)_{2} \mathrm{Zr}_{3} \mathrm{NbSi}_{25} \mathrm{O}_{72}\left(\mathrm{CO}_{3}\right)(\mathrm{OH})_{3}{ }^{*} \mathrm{H}_{2} 0$ and Mogovodite $\mathrm{Na}_{9}(\mathrm{Ca}, \mathrm{Na})_{6} \mathrm{Ca}_{6}\left(\mathrm{Fe}^{3+}{ }_{,} \mathrm{Fe}^{2+}\right)_{2} \mathrm{Zr}_{3}[] \mathrm{Si}_{25} \mathrm{O}_{72}\left(\mathrm{CO}_{3}\right)\left(\mathrm{OH}, \mathrm{H}_{2} \mathrm{O}\right)_{4}$, the new eudialyte-group minerals from high-Calcium agpaitic pegmatites of Kovdor Massif, Kola Peninsula. Zapiski 2005, 6, 36-47. 
3. Khomyakov, A.P.; Dusmatov, V.D.; Ferraris, J. Tsirsilite-(Ce) (Na [] $\left.)_{12}(\mathrm{Ce}, \mathrm{Na})_{3} \mathrm{Ca}_{6} \mathrm{Mn}_{3} \mathrm{Zr}_{3} \mathrm{Nb}_{2} \mathrm{Si}_{25} \mathrm{O}_{73}\right]$ $(\mathrm{OH})_{3}\left(\mathrm{CO}_{3}\right) \cdot \mathrm{H}_{2} \mathrm{O}$ and carbokentbrooksite $(\mathrm{Na},[])_{12}(\mathrm{Na}, \mathrm{Ce})_{3} \mathrm{Ca}_{6} \mathrm{Mn}_{3} \mathrm{Zr}_{3} \mathrm{Nb}\left[\mathrm{Si}_{25} \mathrm{O}_{73}\right](\mathrm{OH})_{3}\left(\mathrm{CO}_{3}\right) \mathrm{H}_{2} \mathrm{O}$, new minerals of Eudialyte group from the Dara-i-Pioz alkaline pluton, Tajikistan. Zap. Vseross. Mineral. O. Va 2003, 132, 40-51.

4. Schilling, J.; Marks, M.; Wenzel, T.; Markl, G. Reconstruction of magmatic to sub-solidus processes in an agpaitic system using eudialyte textures and composition: A case study from Tamazeght, Morocco. Cand. Min. 2009, 47, 351-365. [CrossRef]

5. Rastsvetaeva, R.K.; Chukanov, N.V. Classification of eudialyte-group minerals. Geol. Ore Dep. 2012, 54, 487-497. [CrossRef]

6. Pfaff, K.; Wenzel, T.; Schilling, J.; Marks, M.A.; Markl, G. A fast and easy-to-use approach to cation site assignment for eudialyte-group minerals. J. Mineral. Geochem. 2010, 187, 69-81. [CrossRef]

7. Andersen, T.; Erambert, M.; Larsen, A.O.; Selbekk, R.S. Petrology of nepheline syenite pegmatites in the Oslo rift, Norway: Zirconium silicate mineral assemblages as indicators of alkalinity and volatile fugacity in mildly agpaitic magma. J. Petrol. 2010, 51, 2303-2325. [CrossRef]

8. Mikhailova, J.A.; Ivanyuk GYu Kalashnikov, A.O.; Pakhomovsky, Y.A.; Bazai, A.V.; Yakovenchuk, V.N. Petrogenesis of the Eudialyte complex of the Lovozero alkaline Massif (Kola Peninsula, Russia). Minerals 2019, 9, 581. [CrossRef]

9. Lindhuber, M.J.; Marks, M.A.W.; Bons, P.D.; Wenzel, T.; Markl, G. Crystal mat-formation as an igneous layering-forming process: Textural and geochemical evidence from the 'lower layered' nepheline syenite sequence of the Ilimaussaq complex, South Greenland. Lithos 2015, 224, 295-309. [CrossRef]

10. Ratschbacher, B.C.; Marks, M.A.W.; Bons, P.D.; Wenzel, T.; Markl, G. Emplacement and geochemical evolution of highly evolved syenites investigated by a combined structural and geochemical field study: The lujavrites of the Ilímaussaq complex, SW Greenland. Lithos 2015, 231, 62-76. [CrossRef]

11. Stromeyer, F. Summary of meeting 16 December 1819 (Analyse einiger grönlandischen, von Prof Giesecke erhaltenen Fossilien). Göttingische Gelehrt. Anz. 1819, 3, 1993-2000.

12. Petersen, O.V.; Johnsen, O.; Gault, R.A.; Niedermayr, G.; Grice, J.D. Taseqite, a new member of the eudialyte. Group from the Ilimuassaq alkaline complex, South Greenland. N. Jb. Miner. Mh. 2004, 2, 83-96. [CrossRef]

13. Ferguson, J. Geology of the Ilímaussaq alkaline intrusion, South Greenland. Bull. Grønl. Geol. Unders. 1964, $39,82$.

14. Hamilton, E.I. The geochemistry of the northern part of the Ilímaussaq intrusion, S.W. Greenland. Bull. Grønl. Geol. Unders. 1964, 42, 104.

15. Rose-Hansen, J.; Sørensen, H. Geology of the Lujavrites from the Ilímaussaq alkaline complex South Greenland, with information from seven bore holes. Medd. Grønland Geosc. 2002, 40, 58.

16. Sørensen, H. Brief introduction to the geology of the Ilímaussaq alkaline complex, South Greenland, and its exploration history. Geol. Greenl. Surv. Bull. 2001, 190, 7-24. [CrossRef]

17. Sørensen, H. The Ilímaussaq Alkaline complex, South Greenland-An overview of 200 years of research and an outlook. Medd. Grønland Geosc. 2006, 45, 10-31.

18. Marks, M.A.W.; Markl, G. The Ilímaussaq alkaline complex, South Greenland. In Layered Intrusions; Charlier, B., Namur, O., Latypov, R., Tegner, C., Eds.; Springer: Dordrecht, The Netherlands, 2015; pp. 649-691.

19. Larsen, L.M.; Sørensen, H. The Ilimaussaq intrusion-progressive crystallization and formation of layering in an agpaitic magma. Geol. Soc. London Special Publ. 1987, 30, 473-488. [CrossRef]

20. Pfaff, K.; Krumrei, T.V.; Marks, M.; Wenzel, T.; Rudolf, T.; Markl, G. Chemical and physical evolution of the 'lower layered series' from the nepheline syenitic Ilímaussaq intrusion, South Grenland: Implications for the origin of magmatic layering in peralkaline felsic liquids. Lithos 2008, 106, 280-296. [CrossRef]

21. Borst, A.M.; Friis, H.; Nielsen, T.F.D.; Waight, T.E. Bulk and mush melt evolution in agpaitic intrusions: Insights from compositional zoning in eudialyte, Ilímaussaq complex, South Greenland. J. Petrol. 2018, 59, 589-612. [CrossRef]

22. Hunt, E.J.; Finch, A.A.; Donaldson, C.H. Layering in peralkaline magmas, Ilímaussaq complex, S Greenland. Lithos 2017, 268, 1-15. [CrossRef]

23. Bons, P.D.; Baur, A.; Elburg, M.A.; Lindhuber, M.J.; Marks, M.A.W.; Soesoo, A.; van Milligen, B.P.; Walte, N.P. Layered intrusions and traffic jams. Geology 2015, 43, 71-74. [CrossRef] 
24. Bohse, H.; Brooks, C.K.; Kunzendorf, H. Field observations on the Kakortokites of the Ilímaussaq intrusion, South Greenland, including mapping and analyses by portable x-ray fluorescence equipment for zirconium and niobium. Rapp. Grønl. Geol. Under. 1971, 38, 43.

25. Hunt, E.J. Magma Chamber Dynamics in the Peralkaline Magmas of the Kakortokite Series, South Greenland. Ph.D. Thesis, University of St. Andrews, St. Andrews, UK, 2015.

26. Kümmel, S. Petrologie und Mineralchemie diskordanter Gesteine in den geschichteten Kakortokiten der Ilimaussaq-Intrusion in Südgrönland. Master's Thesis, University of Tübingen, Tübingen, Germany, 2019.

27. Andersen, S.; Bohse, H.; Steenfelt, A. A geological section through the southern part of the Ilímaussaq intrusion. Rapp. Grønl. Geol. Unders. 1981, 103, 39-42.

28. Bohse, H.; Andersen, S. Review of the stratigraphic divisions of the kakortokite and lujavrite in southern Ilímaussaq. Rapp. Grønl. Geol. Unders. 1981, 103, 53-62.

29. Andersen, T.; Sørensen, H. Stability of naujakasite in hyperagpaitic melts, and the petrology of naujakasite lujavrite in the Ilímaussaq alkaline complex, South Greenland. Mineral. Mag. 2005, 69, 125-136. [CrossRef]

30. Sørensen, H.; Bohse, H.; Bailey, J.C. The origin and mode of emplacement of lujavrites in the Ilímaussaq alkaline complex, South Greenland. Lithos 2006, 91, 286-300. [CrossRef]

31. Sørensen, H.; Bailey, J.C.; Rose-Hansen, J. The emplacement and crystallization of the U-Th-REE-rich agpaitic and hyperagpaitic lujavrites at Kvanefjeld, Ilímaussaq alkaline complex, South Greenland. Bull. Geol. Soc. Den. 2011, 59, 69-92.

32. Bailey, J.C.; Gwozdz, R.; Rose-Hansen, J.; Sørensen, H. Geochemical overview of the Ilimaussaq alkaline complex, South Greenland. Geol. Greenl. Surv. Bull. 2001, 190, 35-53.

33. Shore, M.; Fowler, A.D. Oscillatory zoning in minerals; a common phenomenon. Cand. Mineral. 1996, 34, 1111-1126.

34. Borst, A.M.; Friis, H.; Andersen, T.; Waight, T.E.; Nielsen, T.F.D.; Smit, M. Zirconosilicates in the kakortokites of the Ilimaussaq complex, South Greenland: Implications for fluid evolution and HFSE-REE mineralization in agpaitic systems. Mineral. Mag. 2016, 80,1-26. [CrossRef]

35. Schilling, J.; Wu, F.Y.; McCammon, C.; Wenzel, T.; Marks, M.A.W.; Pfaff, K.; Jacob, D.E.; Markl, G. The compositional variability of eudialyte-group minerals. Mineral. Mag. 2011, 75, 87-115. [CrossRef]

36. Hagen, M. Igneous Layering: Mineralogic and Petrologic Analysis of Slightly-layered Kakortokites (SLK's) and Lower layered Kakortokites (LLK's) of the Ilimaussaq Intrusion, Southwest Greenland. Master's Thesis, University of Tübingen, Tübingen, Germany, 2019.

37. Mundel, F. Igneous Layering in the Lowermost Units of the Eudialyte-bearing Nepheline Syenitic Kakortokites, Ilímaussaq Alkaline Complex, South Greenland. Master's Thesis, University of Tübingen, Tübingen, Germany, 2019.

38. Atanasova, P.; Krause, J.; Möckel, R.; Osbahr, I.; Gutzmer, J. Electron probe microanalysis of REE in eudialyte group minerals: Challenges and solutions. Microsc. Microanal. 2015, 21, 1096-1113. [CrossRef] [PubMed]

39. Eggenkamp, H.; Marks, M.A.W.; Atanasova, P.; Wenzel, T.; Markl, G. Chnages in halogen (F, Cl, Br, and I) and $\mathrm{S}$ ratios in rock forming minerals as monitors for magmatic differentiation, volatile loss, and hydrothermal overprint: The case for peralkaline systems. Minerals 2020. submitted. [CrossRef]

40. Johnsen, O.; Ferraris, G.; Gault, R.A.; Grice, J.D.; Kampf, A.R.; Pekov, I.V. The nomenclature of eudialyte-group minerals. Cand. Mineral. 2003, 41, 785-794. [CrossRef]

41. Johnsen, O.; Grice, J.D. The crystal chemistry of the eudialyte group. Cand. Mineral. 1999, 37, 865-891.

42. Coulson, I.M. Post-magmatic alteration in eudialyte from the North Qôroq centre, South Greenland. Mineral. Mag. 1997, 61, 99-109. [CrossRef]

43. Khomyakov, A.P.; Korovuskhin, V.V.; Perfilief, Y.D.; Cherepanov, V.M. Location, valence states, and oxidation mechanism of iron in eudialyte-group minerals from Mössbauer spectrooscopy. Phys. Chem. Minerals 2010, 37, 543-554. [CrossRef]

44. Giehl, C.; Marks, M.A.W.; Nowak, M. An experimental study on the influence of fluorine and chlorine on phase relations in peralkaline phonolitic melts. Contrib. Min. Pet. 2014, 167, 977. [CrossRef]

45. Marks, M.; Coulson, I.M.; Schilling, J.; Jacob, D.E.; Schmitt, A.K.; Markl, G. The effect of titanite and other HFSE-rich mineral (Ti-bearing andradite, zircon, eudialyte) fractionation on the geochemical evolution of silicate melts. Chem. Geol. 2008, 257, 153-172. [CrossRef]

46. Larsen, L.M. Aenigmatites. From the Ilímaussaq intrusion, south Greenland: Chemistry and petrological implications. Lithos 1997, 10, 257-270. [CrossRef] 
47. Rønsbo, J.G.; Sørensen, H.; Roda-Robles, E.; Fontan, F.; Monchoux, P. Rinkite-nacareniobsite-(Ce) solid solution series and hainite from the Ilimaussaq alkaline complex: Occurrence and compositional variation. Bull. Geol. Soc. Denmark 2014, 62, 1-15.

48. Mitchell, R.H.; Chakrabarty, A. Paragenesis. And decomposition assemblage of a Mn-rich eudialyte from the Sushina peralkaline nepheline syenite gneiss, Pachim Bnaga, India. Lithos 2013, 152, 218-226. [CrossRef]

49. Mitchell, R.H.; Liferovich, R.P. Subsolidus deuteric/hydrothermal alteration of eudialyte in lujavrite from the Pilansberg alkaline complex, south Africa. Lithos 2006, 91, 353-372. [CrossRef]

50. Graser, G.; Markl, G. Ca-rich ilvaite-epidote-hydrogarnet endoskarns: A record of late-magmatic fluid influx into the persodic Ilímaussaq complex, South Greenland. J. Petrol. 2008, 49, 239-265. [CrossRef]

51. Marks, M.A.W.; Hettmann, K.; Schilling, J.; Frost, B.R.; Markl, G. The mineralogical diversity of alkaline igneous rocks: Critical factors for the transition from miaskitic to agpaitic phase assemblages. J. Petrol. 2011, 52, 439-455. [CrossRef]

52. Minissale, S.; Zanetti, A.; Tedesco, D.; Morra, V.; Melluso, L. The petrology and geochemistry of Nyiragongo lavas of 2002, 2016, 1977 and 2017 AD, and the trace element partitioning between melilitite glass and melilite, nepheline, leucite, clinopyroxene, apatite, olivine and Fe-Ti oxides: A unique scenario. Lithos 2019, 332, 296-311. [CrossRef]

53. Zahoransky, T.; Friis, H.; Marks, M.A.W. Luminescence and tenebrescence of natural sodalites: A chemical and structural study. Phys. Chem. Mineral. 2016, 43, 459-480. [CrossRef]

Publisher's Note: MDPI stays neutral with regard to jurisdictional claims in published maps and institutional affiliations.

(C) 2020 by the authors. Licensee MDPI, Basel, Switzerland. This article is an open access article distributed under the terms and conditions of the Creative Commons Attribution (CC BY) license (http://creativecommons.org/licenses/by/4.0/). 